удК 616.314+616.716.8]:616.74:[616.314.26+616.22-008.5]-08

DOI 10.11603/2311-9624.2018.4.9630

(СП. С. Фліс, Н. В. Ращенко, В. В. Філоненко, А. О. Мельник, Л. О. Етніс

Національний медичний університет імені О. О. Богомольця, м. Київ

(melnik.alona@gmail.com)

\title{
Функціональний стан м'язів зубощелепного апарату до та після лікування дітей з аномаліями прикусу та мовленнєвими порушеннями
}

Резюме. Під час обстеження ортодонтичних пацієнтів були діти з мовленнєвими порушеннями. Міодинамічна рівновага м’язів-антагоністів та синергістів - це відносна стійкість жувальних та мімічних м'язів, що протягом тривалого часу зберігається без помітних коливань, сприяє відносно стабільному стану зубощелепного апарату.

Мета дослідження - визначити функціональний стан м’язів зубощелепного апарату до та після лікування дітей з аномаліями прикусу та мовленнєвими порушеннями.

Матеріали і методи. Для досягнення поставленої мети було прийнято на лікування 44 пацієнти 3 вираженою ортодонтичною патологією та мовленнєвими порушеннями із нормальним слухом та інтелектом. Для визначення та аналізу показників біоелектричної активності м’язів використано метод сумарної (поверхневої) електроміографії.

Результати досліджень та їх обговорення. Після проведеного лікування спостерігали нормалізацію показників біоелектричної активності, зменшення парафункціональних проявів у м’язах та частоти спалахів спонтанної активності м’язів у стані спокою, нормалізацію середньої амплітуди біопотенціалів у стані активності, відсутність фрагментацій, покращення синхронності та координації скорочень обстежених м'язів при усіх патологіях прикусу.

Висновки. Проведене ортодонтичне лікування забезпечило відновлення нейром'язового балансу зубощелепного апарату пацієнтів із різними патологіями прикусу, що має сприятливий вплив на корекцію мовленнєвих порушень.

Ключові слова: мовленнєві порушення; аномалії прикусу; міографія.

(СП. С. Флис, Н. В. Ращенко, В. В. Филоненко, А. А. Мельник, Л. А. Этнис

Национальный медицинский университет имени А. А. Богомольца, г. Киев

\section{Функциональное состояние мышц зубочелюстного аппарата до и после лечения детей с аномалиями прикуса и речевыми нарушениями}

Резюме. При обследовании ортодонтических пациентов были дети с речевыми нарушениями. Миодинамическое равновесие мышц-антагонистов и синергистов - это относительная устойчивость жевательных и мимических мышц, которая в течении длительного времени сохраняется без заметных изменений, способствует относительной стабильности зубочелюстного аппарата.

Цель исследования - определить функциональное состояние мышц зубочелюстного аппарата до и после лечения детей с аномалиями прикуса и речевыми нарушениями.

Материалы и методы. Для достижения поставленной цели было принято на лечение 44 пациента с выраженной ортодонтической патологией и речевыми нарушениями с нормальным слухом и интеллектом. Для определения и анализа показателей биоэлектрической активности мышц использован метод суммарной (поверхностной) электромиографии.

Результаты исследований и их обсуждение. После проведённого лечения наблюдали нормализацию показателей биоэлектрической активности, уменьшение парафункциональних проявлений в мышцах и частоты вспышек спонтанной активности мышц в состоянии покоя, нормализацию средней амплитуды биопотенциалов в состоянии активности, отсутствие фрагментаций, улучшение синхронности и координации сокращений обследованных мышц при всех патологиях прикуса.

Выводы. Проведённое ортодонтическое лечение обеспечило восстановление нейромышечного баланса зубочелюстного аппарата пациентов с различными патологиями прикуса, что имеет благоприятное воздействие на коррекцию речевых нарушений. 


\section{Functional status of muscles of the dentoalveolar apparatus before and after treatment of children with anomalies of bite and speech disorders}

Summary. During the examination of orthodontic patients, children with speech disorders were found. The myodynamic balance of antagonistic muscles and synergistic muscles is the relative stability of masticatory and mimic muscles, which for a long time persists without noticeable oscillations, contributes to the relatively stable state of dentoalveolar apparatus.

The aim of the study - to determine the functional status of muscles of the dentoalveolar apparatus before and after treatment of children with anomalies of bite and speech disorders.

Materials and Methods. To achieve study objectives for treatment we selected 44 patients with severe orthodontic pathology and speech disorders, with normal hearing and intellect. The method of a total (surface) electromyography was used to determine and analyze the indices of bioelectric activity of the muscles.

Results and Discussion. There was normalization of parameters of bioelectric activity, decrease of parafunctional manifestations in muscles and decrease of the frequency of outbreaks of spontaneous activity of muscles at rest; normalization of the average amplitude of biopotentials in the state of activity, absence of fragmentation, improvement of synchronization and coordination of contractions of examined muscles in all pathologies of dental occlusion after the treatment.

Conclusions. The orthodontic treatment performed provided the restoration of the neuromuscular balance of the dentoalveolar apparatus of patients with various dental occlusion pathologies, which has a beneficial effect on the correction of speech disorders.

Key words: speech disorders; anomalies of bite; myography.

Вступ. Порушення в розвитку зубощелепного апарату завдають шкоди не тільки здоров’ю дитини, але і негативно впливають на їі адаптацію в соціальному середовищі [1, 2].

Аномалії та деформації зубощелепного апарату перешкоджають нормальній артикуляції звуків, сприяють закріпленню звичок неправильної артикуляції і ускладнюють їх логопедичну корекцію. Під час обстеження ортодонтичних пацієнтів були діти з мовленнєвими порушеннями [3-6].

Фізіологічний прикус характеризують лицеві ознаки, ознаки, властиві фізіологічному стану прикусу та скронево-нижньощелепних суглобів, біодинамічна рівновага м'язів щелепно-лицевої ділянки. Міодинамічна рівновага м'язів-антагоністів та синергістів - це відносна стійкість жувальних та мімічних м'язів, що протягом тривалого часу зберігається без помітних коливань, сприяє відносно стабільному стану зубощелепного апарату. Вона порушується під впливом багатьох зовнішніх та внутрішніх факторів, що діють на організм, унаслідок чого можуть формуватись зубощелепні аномалії [5-7, 11-14].

Метою дослідження було визначити функціональний стан м’язів зубощелепного апара- ту до та після лікування дітей 3 аномаліями прикусу та мовленнєвими порушеннями

Матеріали і методи. Для досягнення поставленої мети було прийнято на лікування 44 пацієнти з вираженою ортодонтичною патологією та мовленнєвими порушеннями із нормальним слухом та інтелектом. Ортодонтичне обстеження та лікування проводилося на базі Стоматологічного медичного центру Національного медичного університету імені О. О. Богомольця, логопедичне - у Національній дитячій спеціалізованій лікарні ОХМАТДИТ МОЗ України.

Клінічне обстеження проводили за загальноприйнятою схемою та включало в себе: збір анамнезу, об’єктивні та додаткові методи обстеження. Для виявлення мовленнєвих порушень проводили логопедичну діагностику всіх сторін мови, а саме, звуковимову, лексику, граматику, фонетику. При детальному зборі анамнезу фіксували наступні зауваження: утруднене відкушування та пережовування їжі, неможливість повного контакту зубних рядів. Більшість пацієнтів скаржилась на естетичний дефект. Скарга дітей (батьків), що першочергово звертались до логопеда, була типова, а саме, що 3 мовою «щось не так». 
Для визначення та аналізу показників біоелектричної активності м'язів ми використали метод сумарної (поверхневої) електроміографії. Вивченню та аналізу підлягали такі м'язи: поверхнева частина власне жувальних, передній пучок скроневих м'язів, круговий м'яз рота, груднинно-ключично-соскоподібні м'язи, передні черевця двочеревцевих м'язів.

Реєстрація та запис електробіопотенціалів проходили симетрично. Дослідження проводили за допомогою восьмиканального електроміографа «BioEMG III» компанії «BioResearch Inc.» (США).

Методика дослідження полягала у накладанні на попередньо знежирену шкіру одноразових електродів (BioFLEX, CША), що мають

a

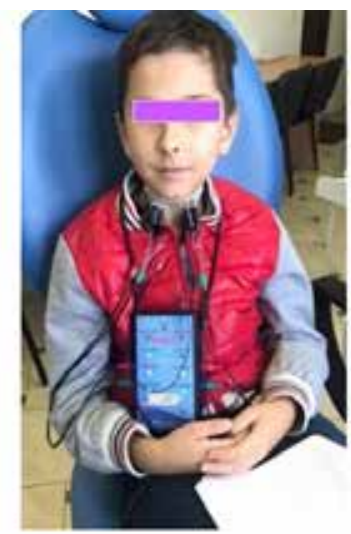

6

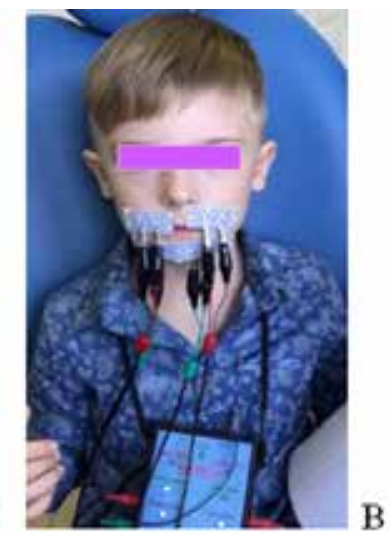

електропровідний гель у проекції моторних точок досліджуваних м'язів. Нейтральний заземлювальний електрод фіксували на шкіру в ділянці дельтоподібного м'яза пацієнта праворуч. Моторні точки жувальних м'язів визначали пальпаторно при максимальній функції м'язів (під час вольового стискання зубів, мовлення та ковтання) у місці їхнього найбільшого випинання. Дослідження проводили в стоматологічному кріслі, у комфортному для пацієнта положенні, коли м'язи спини та шиї не напружені (рис. 1).

Аналізу підлягали наступні функціональні проби: стан фізіологічного спокою, вольове стискання щелеп, ковтання, фонетичні проби.
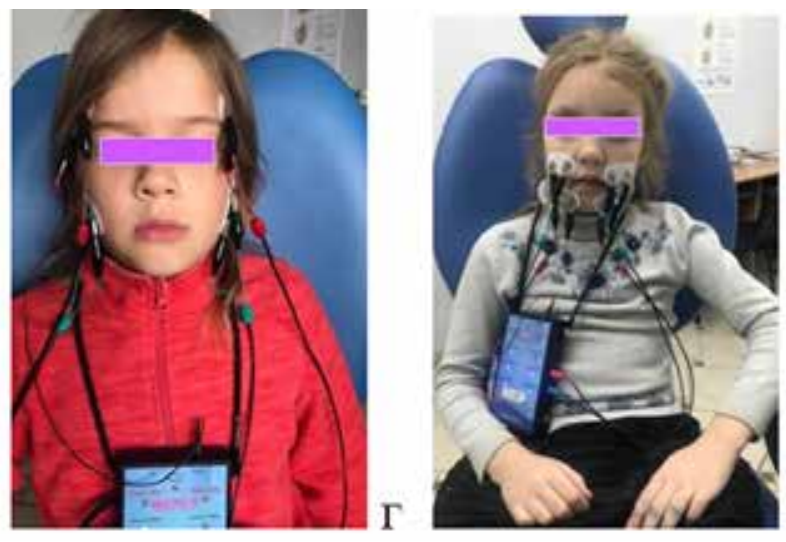

Puc. 1. Загальний вигляд пацієнтів під час електроміографічного дослідження.

Ми дослідили та проаналізували 44 електроміограми пацієнтів до лікування та після його завершення. Одержані результати обробляли на персональному комп’ютері за допомогою спеціалізованого програмного забезпечення (BioPAK, BioRESEARCHAss. Inc., CШA). Аналізу підлягали кількісні та якісні параметри електроміографії: амплітуда біоелектричної активності, симетрія скорочень м'язів справа та зліва, ступінь синхронності та злагодженості роботи м'язів, наявність чи відсутність спонтанної активності у стані спокою, фрагментацій піків під час функції.

Для кількісного аналізу використовували цифрові дані, що були отримані, підсилені електроміографом та вирахувані програмою. Ми проаналізували показники амплітуди біоелектричної активності (mV), симетрії активності м'язів правого та лівого боків (\%).

До початку лікування для визначення функціонального стану зубощелепного апарату було проведено електроміографічне дослідження пацієнтам із дистальним ускладненим глибоким (20 осіб), дистальним (9 осіб), мезіальним (7 осіб), відкритим (8 осіб) прикусами віком від 6 до 12 років. Також проводили електроміографічний контроль нормалізації функції м’язів після завершення лікування для усіх пацієнтів із відповідними патологіями. Висновки робили щодо ефективності та якості проведеного лікування.

Для усунення ортодонтичних патологій користувались знімною (апарати Шварца на нижню чи верхню щелепу, Андрезена-Гойпля, Брюкля-Райхенбаха, апарат Фліса П.С.-Філоненко В. В. для лікування відкритого прикусу) чи незнімною (апарат Марко Росса) ортодонтичною апаратурою залежно від клінічної ситуації та виду патологічного прикусу [5, 8, 9]. Фонетичну корекцію мовлення виконували згідно зі схемою корекції за Н. С. Гавриловою [10]. Логопед проводив артикуляційні вправи для постановки звуків, різні залежно від кількості звуків, що замінені, спотворені чи повністю відсутні.

Результати досліджень та їх обговорення. Електроміографічне дослідження починали 3 вивчення біоелектричної активності м'язів у стані відносного фізіологічного спокою. 
У жувальних та мімічних м’язах були зареєстровані незначні спалахи спонтанної активності (1-3 за 5c) у фазі функціонального спокою при усіх патологіях прикусу, що свідчило про наявність парафункціональних та гіперфункціональних змін (рис. 2, 3).

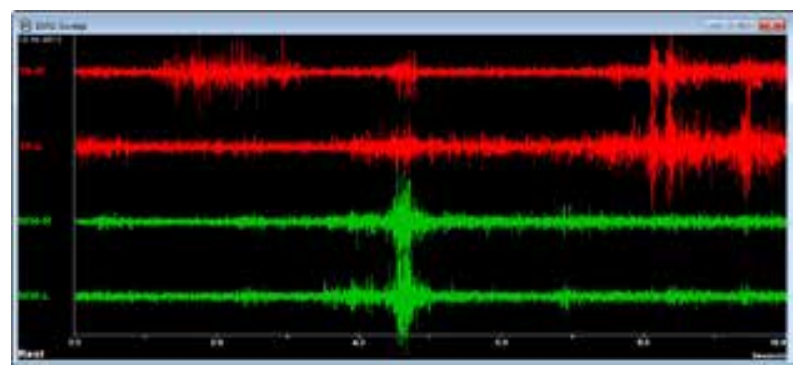

Puc. 2. Спалахи спонтанної активності у жувальних м'язах у стані фізіологічного спокою до початку лікування.

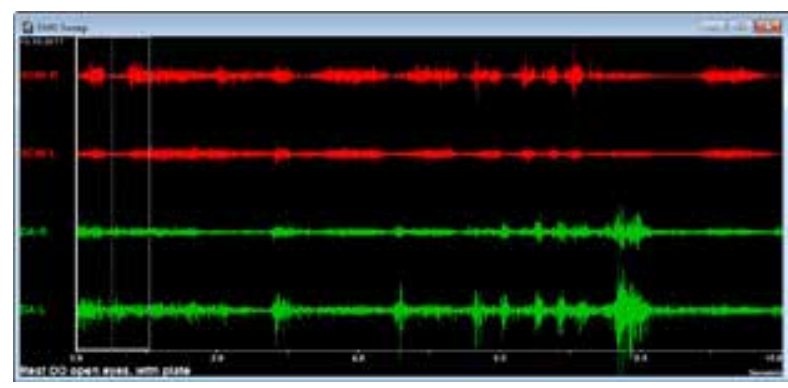

Puc. 3. Спалахи спонтанної активності колового м’яза рота до початку лікування.

У пацієнтів із відкритим прикусом було підвищення біоелектричної активності передніх пучків скроневих м'язів $(4,62 \pm 1,13) \mathrm{mV}$ і верхньої частини колового м'яза рота $(4,51 \pm 1,07)$ $\mathrm{mV}$ у стані спокою (рис. 4).

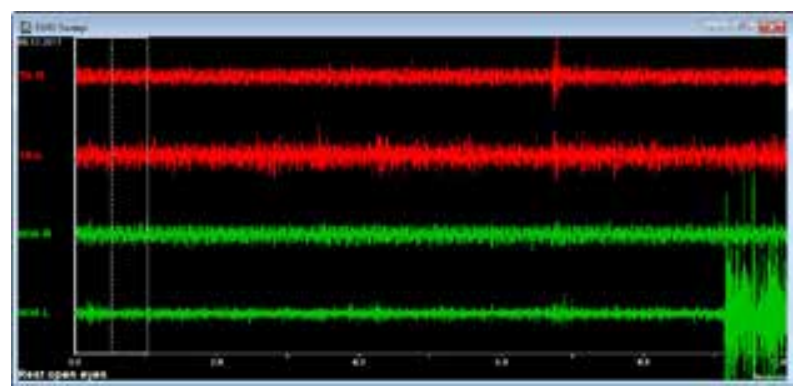

Puc. 4. Підвищена біоелектрична активність скроневих м'язів у стані спокою пацієнта з відкритим прикусом до початку лікування.

Виявлені порушення якісних і кількісних показників електроміографічної характеристики стану жувальних і мімічних м'язів зубощелепної ділянки свідчать про дискоординацію в них збуджувальних процесів, порушення механізмів нервової регуляції.
Наступним етапом було дослідження вольового стискання щелеп, що спостерігали впродовж 10 с. Для електроміограм наших пацієнтів усіх груп патологій були характерні нерівномірні показники амплітуди та частоти виникнення потенціалів у всіх досліджуваних м'язах. Спостерігали асиметрію максимальної біоелектричної активності у власне жувальних та скроневих м'язах справа та зліва (рис. 5).

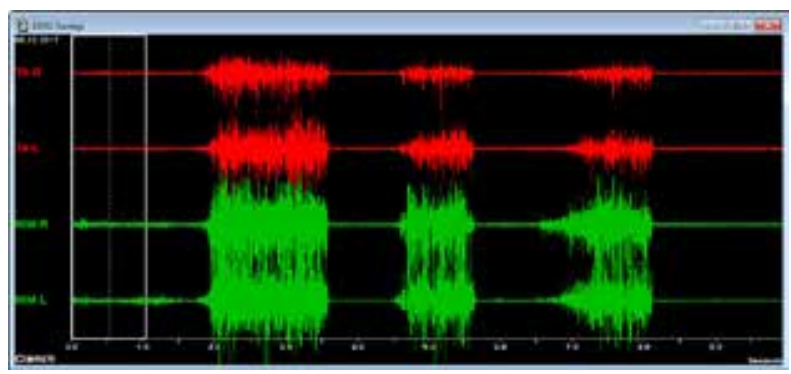

Puc. 5. Ознаки дискоординації роботи жувальних м'язів при стисканні.

Ми виявили, що при мезіальному прикусі реєструють параметри, що свідчать про порушення скоротливої діяльності жувальних м'язів, а саме, значне зменшення активності власне жувальних м'язів $(19,94 \pm 7,37) \mathrm{mV}$ при задовільних показниках у скроневих $(50,35 \pm 6,17) \mathrm{mV}$.

Амплітуда біопотенціалів колового м’яза рота під час функції при дистальному ускладненому глибоким прикусі нижча $((2,24 \pm 1,17) \mathrm{mV}$ верхня частина i $(2,13 \pm 1,02) \mathrm{mV}$ нижня частина)) показників відносної норми, що свідчить про характерні функціональні порушення, які супроводжують патологію прикусу (рис. 6).

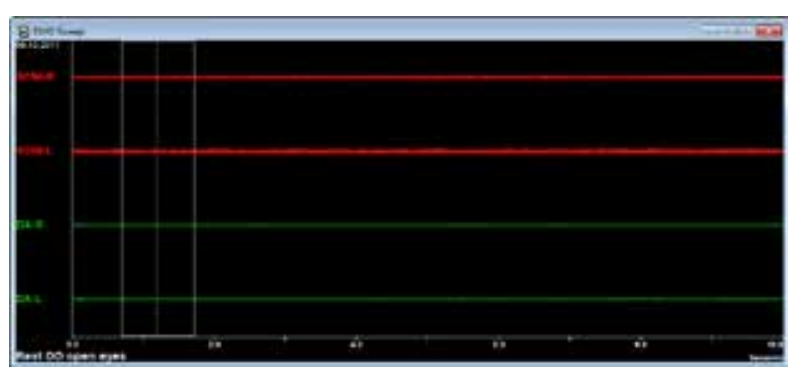

Puc. 6. Знижена активність колового м'яза рота пацієнта при дистальному ускладненому глибоким прикусі.

Аналіз результатів обстеження початкового стану м'язів пацієнтів наведено в таблиці 1.

3 метою моніторингу ефективності ортодонтичного лікування, проведеного нами, було зроблено електроміографічний аналіз пацієнтів після його завершення. 
Дитяча стоматологія

Таблиия 1. Електроміографічні параметри пацієнтів до проведеного лікування

\begin{tabular}{|c|c|c|c|c|c|}
\hline \multirow[b]{2}{*}{ М’яз } & \multirow[b]{2}{*}{ Патологія } & \multicolumn{2}{|c|}{ Стан спокою } & \multicolumn{2}{|c|}{ Вольове стискання } \\
\hline & & $\underset{(\mathrm{mV})}{\mathrm{Amp} \max }$ & $\begin{array}{c}\text { симетрія активності } \\
\text { справа та зліва (\%) }\end{array}$ & $\underset{(\mathrm{mV})}{\mathrm{Amp} \max }$ & $\begin{array}{c}\text { симетрія активності } \\
\text { справа та зліва (\%) }\end{array}$ \\
\hline \multirow[t]{4}{*}{$\begin{array}{l}\text { Поверхнева } \\
\text { частина власне } \\
\text { жувальних }\end{array}$} & $\begin{array}{c}\text { дистальний, } \\
\text { ускладнений } \\
\text { глибоким } \\
\end{array}$ & $1,57 \pm 0,48$ & $87,21 \pm 6,37$ & $68,47 \pm 7,23$ & $82,32 \pm 5,29$ \\
\hline & дистальний & $1,62 \pm 0,53$ & $84,25 \pm 8,36$ & $72,49 \pm 6,71$ & $80,24 \pm 6,07$ \\
\hline & мезіальний & $2,29 \pm 1,03$ & $65,83 \pm 9,45$ & $19,94 \pm 7,37$ & $56,37 \pm 5,76$ \\
\hline & відкритий & $1,43 \pm 0,67$ & $86,72 \pm 7,14$ & $43,22 \pm 8,73$ & $81,62 \pm 4,37$ \\
\hline \multirow[t]{4}{*}{$\begin{array}{l}\text { Передній пучок } \\
\text { скроневих } \\
\text { м’язів }\end{array}$} & $\begin{array}{c}\text { дистальний, } \\
\text { ускладнений } \\
\text { глибоким } \\
\end{array}$ & $1,56 \pm 0,72$ & $65,27 \pm 4,08$ & $78,42 \pm 6,27$ & $72,41 \pm 6,45$ \\
\hline & дистальний & $1,52 \pm 0,64$ & $67,24 \pm 5,32$ & $82,13 \pm 7,09$ & $73,52 \pm 7,54$ \\
\hline & мезіальний & $7,81 \pm 2,07$ & $64,38 \pm 8,91$ & $50,35 \pm 6,17$ & $86,22 \pm 4,29$ \\
\hline & відкритий & $4,62 \pm 1,13$ & $63,36 \pm 2,71$ & $14,27 \pm 4,43$ & $61,36 \pm 6,29$ \\
\hline \multirow[t]{4}{*}{$\begin{array}{l}\text { Круговий м’яз } \\
\text { рота (верхня } \\
\text { частина) }\end{array}$} & $\begin{array}{c}\text { дистальний, } \\
\text { ускладнений } \\
\text { глибоким } \\
\end{array}$ & $2,24 \pm 1,17$ & $75,43 \pm 5,68$ & $15,12 \pm 3,24$ & $71,39 \pm 7,42$ \\
\hline & дистальний & $5,04 \pm 2,01$ & $70,25 \pm 5,39$ & $27,14 \pm 3,46$ & $68,52 \pm 7,09$ \\
\hline & мезіальний & $4,17 \pm 1,23$ & $72,83 \pm 6,24$ & $23,52 \pm 2,68$ & $63,76 \pm 6,82$ \\
\hline & відкритий & $4,51 \pm 1,07$ & $53,54 \pm 2,37$ & $9,25 \pm 2,38$ & $81,37 \pm 5,49$ \\
\hline \multirow[t]{4}{*}{$\begin{array}{l}\text { Круговий м’яз } \\
\text { рота (нижня } \\
\text { частина) }\end{array}$} & $\begin{array}{c}\text { дистальний, } \\
\text { ускладнений } \\
\text { глибоким } \\
\end{array}$ & $2,13 \pm 1,02$ & $72,31 \pm 4,24$ & $16,27 \pm 3,72$ & $68,71 \pm 9,37$ \\
\hline & дистальний & $2,47 \pm 1,15$ & $74,91 \pm 5,78$ & $18,03 \pm 4,33$ & $67,49 \pm 7,18$ \\
\hline & мезіальний & $11,23 \pm 3,07$ & $67,52 \pm 5,43$ & $60,95 \pm 7,41$ & $61,67 \pm 8,14$ \\
\hline & відкритий & $1,95 \pm 0,87$ & $85,71 \pm 4,28$ & $20,43 \pm 7,12$ & $79,53 \pm 9,73$ \\
\hline \multirow{4}{*}{$\begin{array}{l}\text { Груднинно- } \\
\text { ключично- } \\
\text { соскоподібні } \\
\text { м’язи }\end{array}$} & $\begin{array}{c}\text { дистальний, } \\
\text { ускладнений } \\
\text { глибоким }\end{array}$ & $2,91 \pm 0,54$ & $64,27 \pm 6,28$ & $11,78 \pm 2,03$ & $65,07 \pm 6,41$ \\
\hline & дистальний, & $2,84 \pm 0,72$ & $65,13 \pm 5,21$ & $12,44 \pm 1,82$ & $64,27 \pm 5,34$ \\
\hline & мезіальний & $2,65 \pm 0,93$ & $60,18 \pm 7,35$ & $24,21 \pm 2,32$ & $58,63 \pm 10,27$ \\
\hline & відкритий & $2,17 \pm 0,87$ & $62,46 \pm 4,84$ & $26,12 \pm 3,09$ & $62,38 \pm 7,52$ \\
\hline \multirow[t]{4}{*}{$\begin{array}{l}\text { Передні черев- } \\
\text { ця двочеревце- } \\
\text { вих м’язів }\end{array}$} & $\begin{array}{c}\text { дистальний, } \\
\text { ускладнений } \\
\text { глибоким } \\
\end{array}$ & $1,72 \pm 1,01$ & $68,22 \pm 4,21$ & $20,37 \pm 4,83$ & $62,03 \pm 6,94$ \\
\hline & дистальний & $1,47 \pm 0,84$ & $72,21 \pm 9,46$ & $19,84 \pm 3,47$ & $64,27 \pm 8,72$ \\
\hline & мезіальний & $2,35 \pm 0,65$ & $81,76 \pm 6,92$ & $24,95 \pm 4,34$ & $55,93 \pm 7,56$ \\
\hline & відкритий & $3,12 \pm 0,75$ & $78,24 \pm 4,11$ & $26,74 \pm 3,33$ & $58,73 \pm 6,37$ \\
\hline
\end{tabular}

У результаті аналізу даних електроміографії пацієнтів та порівняння іï кількісних та якісних показників доведено, що у пацієнтів після проведеного лікування спостерігали: нормалізацію показників біоелектричної активності, зменшення парафункціональних проявів у м'язах та частоти спалахів спонтанної активності м’язів у стані спокою (рис. 7,8 ).

Також спостерігали нормалізацію середньої амплітуди біопотенціалів у стані активності, відсутність фрагментацій, покращення синхронності та координації скорочень об-

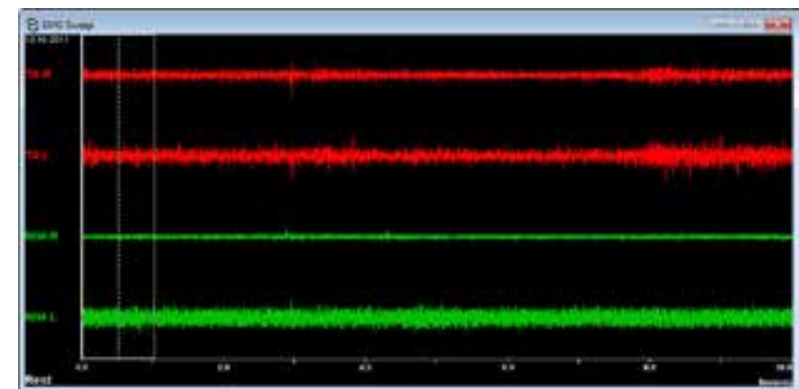

Puc. 7. Задовільні показники активності жувальних м'язів у стані спокою після проведеного лікування. 


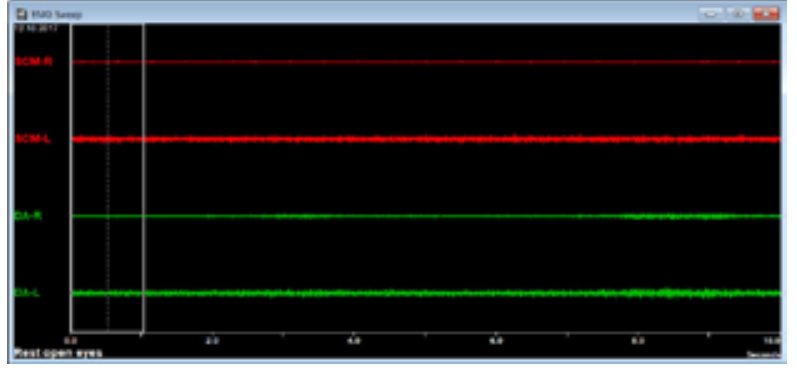

Puc. 8. Відсутність спалахів спонтанної активності колового м’яза рота у стані спокою після проведеного лікування.

стежених м’язів при усіх патологіях прикусу (рис. 9).

Аналіз результатів обстеження стану м’язів пацієнтів після проведеного лікування наведено в таблиці 2.

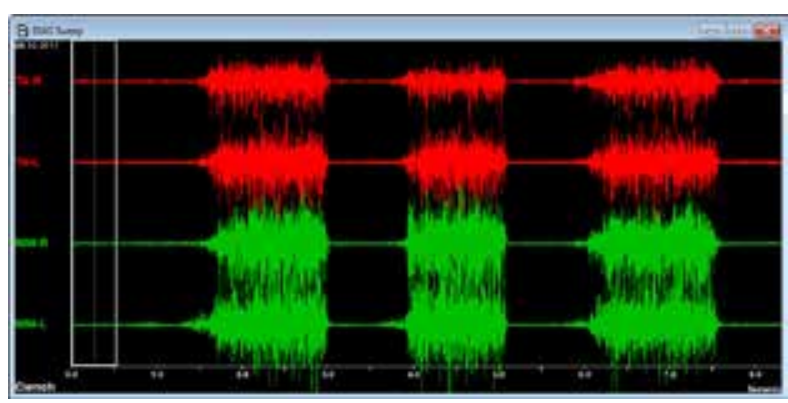

Puc. 9. Нормалізація показників активності жувальних м’язів у стані активності.

Таблищя 2. Електроміографічні параметри пацієнтів після проведеного лікування

\begin{tabular}{|c|c|c|c|c|c|}
\hline \multirow{2}{*}{$\begin{array}{c}\text { Жувальний } \\
\text { м'яз }\end{array}$} & \multirow[b]{2}{*}{ Патологія } & \multicolumn{2}{|c|}{ Стан спокою } & \multicolumn{2}{|c|}{ Вольове стискання } \\
\hline & & $\begin{array}{c}\text { Amp max } \\
(\mathrm{mV})\end{array}$ & $\begin{array}{c}\text { симетрія активності } \\
\text { справа та зліва (\%) }\end{array}$ & $\begin{array}{c}\text { Amp max } \\
(\mathrm{mV})\end{array}$ & $\begin{array}{c}\text { симетрія активності } \\
\text { справа та зліва (\%) }\end{array}$ \\
\hline \multirow[t]{4}{*}{$\begin{array}{l}\text { Поверхнева } \\
\text { частина влас- } \\
\text { не жувальних }\end{array}$} & $\begin{array}{c}\text { дистальний, } \\
\text { ускладнений } \\
\text { глибоким } \\
\end{array}$ & $1,42 \pm 0,64$ & $85,54 \pm 4,97$ & $74,56 \pm 5,98$ & $83,47 \pm 4,18$ \\
\hline & дистальний & $1,38 \pm 0,47$ & $86,13 \pm 6,17$ & $75,27 \pm 4,82$ & $84,37 \pm 5,23$ \\
\hline & мезіальний & $1,32 \pm 0,78$ & $67,18 \pm 7,56$ & $24,48 \pm 6,33$ & $75,82 \pm 4,17$ \\
\hline & відкритий & $0,76 \pm 0,14$ & $87,94 \pm 5,67$ & $67,23 \pm 6,44$ & $92,37 \pm 3,27$ \\
\hline \multirow[t]{4}{*}{$\begin{array}{l}\text { Передній } \\
\text { пучок скроне- } \\
\text { вих м'язів }\end{array}$} & $\begin{array}{c}\text { дистальний, } \\
\text { ускладнений } \\
\text { глибоким } \\
\end{array}$ & $1,32 \pm 0,84$ & $79,42 \pm 3,97$ & $79,15 \pm 5,42$ & $75,38 \pm 5,03$ \\
\hline & дистальний & $1,24 \pm 0,37$ & $80,34 \pm 4,06$ & $83,14 \pm 6,29$ & $77,83 \pm 5,72$ \\
\hline & мезіальний & $2,11 \pm 0,97$ & $78,05 \pm 5,93$ & $48,81 \pm 5,13$ & $88,42 \pm 3,78$ \\
\hline & відкритий & $0,87 \pm 0,22$ & $78,35 \pm 4,17$ & $41,35 \pm 2,34$ & $75,58 \pm 5,11$ \\
\hline \multirow[t]{4}{*}{$\begin{array}{l}\text { Круговий м’яз } \\
\text { рота (верхня } \\
\text { частина) }\end{array}$} & $\begin{array}{c}\text { дистальний, } \\
\text { ускладнений } \\
\text { глибоким } \\
\end{array}$ & $2,76 \pm 1,02$ & $76,12 \pm 7,23$ & $17,22 \pm 4,04$ & $72,42 \pm 6,27$ \\
\hline & дистальний & $3,22 \pm 1,37$ & $72,41 \pm 6,18$ & $16,24 \pm 4,32$ & $71,15 \pm 5,83$ \\
\hline & мезіальний & $2,23 \pm 1,06$ & $76,29 \pm 8,37$ & $21,41 \pm 2,34$ & $68,22 \pm 7,31$ \\
\hline & відкритий & $3,65 \pm 1,24$ & $55,31 \pm 4,91$ & $8,34 \pm 3,51$ & $83,46 \pm 7,82$ \\
\hline \multirow[t]{4}{*}{$\begin{array}{l}\text { Круговий м’яз } \\
\text { рота (нижня } \\
\text { частина) }\end{array}$} & $\begin{array}{c}\text { дистальний, } \\
\text { ускладнений } \\
\text { глибоким } \\
\end{array}$ & $1,78 \pm 0,93$ & $73,27 \pm 5,26$ & $12,47 \pm 4,12$ & $70,72 \pm 6,43$ \\
\hline & дистальний & $2,03 \pm 1,04$ & $75,08 \pm 6,75$ & $15,29 \pm 4,57$ & $69,53 \pm 6,92$ \\
\hline & мезіальний & $10,18 \pm 2,32$ & $71,89 \pm 4,27$ & $34,25 \pm 9,72$ & $73,15 \pm 7,46$ \\
\hline & відкритий & $1,21 \pm 0,67$ & $86,39 \pm 9,17$ & $15,78 \pm 8,23$ & $82,65 \pm 7,04$ \\
\hline \multirow{4}{*}{$\begin{array}{l}\text { Груднинно- } \\
\text { ключично- } \\
\text { соскоподібні } \\
\text { м’язи }\end{array}$} & $\begin{array}{c}\text { дистальний, } \\
\text { ускладнений } \\
\text { глибоким } \\
\end{array}$ & $2,12 \pm 0,72$ & $69,81 \pm 5,73$ & $10,25 \pm 3,17$ & $68,42 \pm 7,24$ \\
\hline & дистальний & $1,92 \pm 0,64$ & $68,24 \pm 6,43$ & $10,84 \pm 2,37$ & $67,37 \pm 6,14$ \\
\hline & мезіальний & $1,97 \pm 0,78$ & $72,68 \pm 6,27$ & $18,47 \pm 3,79$ & $69,31 \pm 8,41$ \\
\hline & відкритий & $1,88 \pm 0,67$ & $65,27 \pm 5,24$ & $16,39 \pm 4,21$ & $65,94 \pm 5,67$ \\
\hline \multirow{4}{*}{$\begin{array}{l}\text { Передні } \\
\text { черевця дво- } \\
\text { черевцевих } \\
\text { м’язів }\end{array}$} & $\begin{array}{c}\text { дистальний, } \\
\text { ускладнений } \\
\text { глибоким } \\
\end{array}$ & $1,15 \pm 0,92$ & $72,43 \pm 5,71$ & $17,21 \pm 5,32$ & $66,24 \pm 5,43$ \\
\hline & дистальний & $1,32 \pm 0,78$ & $75,38 \pm 7,54$ & $15,47 \pm 4,22$ & $68,92 \pm 7,57$ \\
\hline & мезіальний & $2,01 \pm 0,42$ & $83,24 \pm 7,09$ & $16,32 \pm 5,14$ & $67,91 \pm 8,52$ \\
\hline & відкритий & $2,05 \pm 0,96$ & $81,59 \pm 6,23$ & $18,85 \pm 4,82$ & $64,21 \pm 6,77$ \\
\hline
\end{tabular}


Висновки. Враховуючи наведені результати електроміографічного аналізу стану поверхневих частин власне жувальних, передніх пучків скроневих м'язів, кругового м'яза рота, груднинно-ключично-соскоподібних м’язів, передніх черевець двочеревцевих

\section{Список літератури}

1. Фліс П. С. Частота і розповсюдженість аномалій та деформацій зубощелепного апарату в період змінного прикусу / П. С. Фліс, В. В. Філоненко, Н. М. Дорошенко // Український стоматологічний альманах. - 2016. - № 1, т. 1. - С. 75-78.

2. Потапчук А. М. Поширеність зубощелепних аномалій серед дітей шкільного віку Закарпатської області / А. М. Потапчук, О. Ю. Рівіс, К. В. Зомбор // Проблеми клінічної педіатрії. - 2013. - № 1 (19). - С. 58-63. 3. Куроєдова В. Д. Логопедія в ортодонтії / В. Д. Куроєдова, В. А. Сірик. - Полтава : Верстка, 2005. - 124 с.

4. Логопедія / за ред. М. К. Шеремет. - К. : Слово, 2014. $-672 \mathrm{c}$.

5. Фліс П. С. Ортодонтія / П. С. Фліс. - Вінниця : Нова книга, 2007. - 312 с.

6. Хорошилкина Ф. Я. Ортодонтия. Дефекты зубов, зубных рядов, аномалии прикуса, морфофункциональные нарушения в челюстно-лицевой области и их комплексное лечение / Ф. Я. Хорошилкина. - М. : МИА, 2006. - 395 с.

7. Головко Н. В. Ортодонтія. Розвиток прикусу, діагностика зубощелепних аномалій, ортодонтичний діагноз / Н. В. Головко. - Полтава : ПФ «Форпіка», 2003. $-170 \mathrm{c}$.

8. Атлас ортодонтических аппаратов / [В. Д. Куроедова, В. Н. Ждан, Л. Б. Галич и др.]. - Полтава : Дивосвіт, 2011. - 154 с.

\section{References}

1. Flis, P.S., Filonenko, V.V., \& Doroshenko, N.M. (2016). Chastota i rozpovsyudzhenist anomalii ta deformatsii zuboshchelepnoho aparatu v period zminnoho prykusu [Frequency and prevalence of abnormalities and deformations of the dento-jaw apparatus during the period of occlusive bite]. Ukrainskyi stomatolohichnyi almanakh - Ukrainian Dental Almanac, 1, 1, 75-78 [in Ukrainian].

2. Potapchuk, A.M., Rivis, O.Yu., \& Zombor, K.V. (2013). Poshyrenist zuboshchelepnykh anomalii sered ditei shkilnoho viku Zakarpatskoi oblasti [The prevalence of tooth-abdominal anomalies among children of school age in the Transcarpathian region]. Problemy klinichnoi pediatrii - Problems of Clinical Pediatrics, 1 (19), 58-63 [in Ukrainian].

3. Kuroiedova, V.D., \& Siryk, V.A. (2005). Lohopediia $v$ ortodontii [The speech therapy in orthodontics]. Poltava: Verstka [in Ukrainian].

4. Sheremet, M.K. (Ed.) (2014). Lohopediia [Speech therapy]. Kyiv: Slovo [in Ukrainian].

5. Flis, P.S. (2007). Ortodontiia [Orthodontics]. Vinnytsia: Nova knyha [in Ukrainian].

6. Khoroshilkina. F.Ya.(2006). Ortodontiia. Defekty zubov, м'язів, можна зазначити, що проведене нами ортодонтичне лікування забезпечило відновлення нейром'язового балансу зубощелепного апарату пацієнтів із різними патологіями прикусу, що має сприятливий вплив на корекцію мовленнєвих порушень.

9. Orthodontics. Dentognathic anomalies and deformations: textbook / P. S. Flis, G. P. Leonenko, V. V. Filonenko, N. M. Doroshenko; In P. S. Flis ed. - K. : AUS Medicine Publishing, 2015. - 176 p.

10. Гаврилова Н. С. Система корекції порушень фонетичного боку мовлення / Н. С. Гаврилова // Науковий часопис НПУ імені М. П. Драгоманова. Серія 19 : Корекційна педагогіка та спеціальна психологія. 2014. - Вип. 27. - С. 37-44.

11. Доусон П. Е. Функциональная окклюзия: от височнонижнечелюстного сустава до планирования улыбки / П. Е. Доусон (пер. с англ.) ; под ред. Д. Б. Конева. - М. : Практическая медицина, 2016. - 592 с.

12. Костюк Т. М. Клінічна діагностика, ортопедичне лікування та профілактика оклюзійних порушень, які виникли внаслідок прорізування третіх моляpiв : дис. на здобуття наук. ступеня канд. мед. наук : 14.01.22 / Т. М. Костюк. - Нац. мед. ун-т ім. О. О. Богомольця. - К., 2011. - 162 с.

13. Косырева Т. Ф. Электромиографическая оценка результатов ортодонтического лечения с использованием преортодонтических трейнеров / Т. Ф. Косырева, Е. В. Кулакова, Н. В. Вильневчин // Ортодонтия. - 2008. - № 2 (42). - С. 24-29.

14. Николаев С. Г. Электромиография: клинический практикум / С. Г. Николаев. - Иваново, 2013. - 264 с.

zubnykh ryadov, anomalii prikusa, morfofunktsionalnyye narusheniya $v$ chelyustno-litsevoy oblasti $i$ ikh kompleksnoye lecheniye [Orthodontics. Defects of teeth, dentition, occlusion anomalies, morphofunctional disorders in the maxillofacial area and their complex treatment]. Moscow: MIA [in Russian].

7. Holovko, H.B. (2003). Ortodontiia. Rozvytok prykusu, diahnostyka zuboshchelepnykh anomalii, ortodontychnyi diahnoz [Orthodontics. Development of bite, diagnosis of tooth-jaw abnormalities, orthodontic diagnosis]. Poltava: PF "Forpika" [in Ukrainian].

8. Kuroyedova, V.D., Zhdan, V.N., Galich, L.B. Golovko, N.V., Dmitrenko, M.I., Siryk, V.A., \& Kuroyedova, Ye.L. (2011). Atlas ortodonticheskikh apparatov [Atlas of orthodontic devices]. Poltava: Dyvosvit [in Ukrainian]. 9. Flis, P.S., Leonenko, G.P., Filonenko, V.V., \& Doroshenko, N.M. (2015). Orthodontics. Dentognathic Anomalies and Deformations: textbook; Flis, (Ed.). Kyiv: AUS Medicine Publishing.

10. Havrylova, N.S. (2014). Systema korektsii porushen fonetychnoho boku movlennia [System of correction of violations of the phonetic side of speech]. Naukovyi chasopys NPU imeni M.P. Drahomanova. Seriia 19: 
Korektsiina pedahohika ta spetsialna psykholohiia Scientific Journal of M.P. Drahomanov NPU. Series 19: Correctional Pedagogy and Special Psychology, 27, 37-44 [in Ukrainian].

11. Douson, P.Ye. (2016). Funktsionalnaya okklyuziya: ot visochnonizhnechelyustnogo sustava do planirovaniya ulybki [Functional occlusion: from the temporomandibular joint to the smile planning]. Koneva, D.B. Ed.. (Transl. from En.). Moscow: Prakticheskaya Meditsina [in Russian].

12. Kostyuk, T.M. (2011). Klinichna diahnostyka, ortopedychne likuvannia ta profilaktyka okliuziinykh porushen, yaki vynykly vnaslidok prorizuvannia tretikh moliariv [Clinical diagnostics, orthopedic treatment and prophylaxis of occlusive disorders that arose as a result of the eruption of third molars]. Candidate's thesis. Kyiv [in Ukrainian].

13. Kosyreva, T.F., Kulakova, Ye.V., \& Vilnevchin, N.V. (2008). Elektromiograficheskaya otsenka rezultatov ortodonticheskogo lecheniya s ispolzovaniyem preortodonticheskikh treynerov [The electromyographic assessment of the results of orthodontic treatment using pre-orthodontic trainers]. Ortodontiya-Orthodontics, 2 (42), 24-29 [in Russian].

14. Nikolayev, S.G. (2013). Elektromiografiya: klinicheskiy praktikum [Electromyography: Clinical Workshop]. Ivanovo [in Russian].

Отримано 03.09.18 